\title{
Textual Labyrinths: Toward a Labyrinthine Aesthetic
}

Nemo ambigit ... cum aliqua difficultate quaesita multo gratius inveniri.

What is sought with difficulty is discovered with more pleasure.

Augustine, On Christian Doctrine 2.8 (13)

7 HE PREvious chapter looked at labyrinths in medieval texts; now we turn to a broader subject: the text, and the complex intellectual processes related to its creation and reception, as labyrinth. The essential qualities of the labyrinth, defined in Chapter 2 , remain the basis of these speculations on the inherent labyrinthicity of much medieval literature and literary theory. A text that is wellconstructed according to medieval theories of rhetoric is, as we will see, of ten very like a maze: it is an ornate, highly complicated work of art, elegantly ordered by interwoven parts comprising an admirable whole. ${ }^{1}$ As the text itself is a labyrinthine artifact, so its creation and reception are labyrinthine processes. Its labor intus implies both the author's meticulous workmanship and the reader's painstaking interpretation. And because labyrinthine texts are so complex, apprehension of the whole may be thwarted by inextricable immersion in its parts: writers and readers may not achieve the privileged understanding that patterns and makes sense of internal errores and ambages. Would-be Daedalian writers may grow bewildered by the sheer proliferation of their sources or their own verbiage; readers or listeners may be so disoriented by elaborate amplification, circuitous expression, and a multiplicity of interpretive

1. Medieval rhetorical writings included treatises on poetry, letter-writing, and preaching. 
options that they lose all sense of the whole or even abandon the pursuit of a center entirely, closing the manuscript or sleeping through the sermon. Intellectual and literary labyrinths can be as inextricable and inexplicable as architectural ones, an idea we have already encountered in Chapter 3.

Verbal mazes are also convertible and perspective-dependent: the very ambages that confuse one reader or listener may delight another and lead him or her to a transcendent vision of the whole, and a work that is enigmatic on one reading may yield precious knowledge when its windings are probed a second or third time. Persistence pays of $f$ with difficult texts as it does with mazes, and appropriate guidance, like the interpretive statements embedded in the Queste del Saint Graal or the leading questions of the old man in the Corbaccio or the moral appended to the Gesta tale or Jerome's commentary on Ezekiel, can of ten help.

The labyrinthine characteristic most prominent in intellectual and textual mazes is difficult, circuitous process: per ardua ad astra. Of ten this elaborate process is prescribed by what I will call the labyrinthine aesthetic of much medieval literature, an aesthetic outlined in rhetorical handbooks and defenses of poetry. Difficulty is privileged partly as a method of attaining elegance and well-wrought artistry; partly as a way of keeping the unworthy from profaning the finer achievements of civilization; and partly as a pedagogical technique to ensure that knowledge, once gained, is appreciated.

The labyrinthicity of intellectual and textual processes may be seen as good or bad. If the artistic design of the whole work succeeds, the labyrinthine process functions in bono, and the artistry is penetrable and perceptible to those meant to penetrate and perceive. But when artistic complexity goes awry, serving an unworthy end or leaving its intended audience imprisoned in complexity - when the textual labyrinth is inextricable, in short-it is to be condemned. Thus the labyrinths of scripture, esteemed by Rudolf of Saint Trond as by Jerome, are admirable, whereas the heretical labyrinths woven by Peter Abelard, according to Walter of Saint Victor, are not-at least to their critics. Similarly, the difficulties of complex literature, praised by lovers of rhetoric like Geoffrey of Vinsauf and Boccaccio, are problematic for pastors like Hugh of Saint Victor and Robert of Basevorn, who privilege the spiritual needs of unsophisticated audiences easily confused by rhetorical devices that enchant the learned; the crucial issue is whether the complex work is penetrable and extricable or not, and for whom. Good textual labyrinths exercise the mind of the creator and interpreter, leading to a goal of enlightenment for the intended reader; bad labyrinths involve art in the service of a bad master or, alternatively, language so complex that the intellectual wayfarer is sidetracked when a more direct path or a plainer 
style might have taught him something. Labyrinthine complexity and convertibility, then, may be assets or liabilities.

Parts of this chapter involve a fair degree of speculative interpretation of medieval evidence. I am going to argue that the idea of the labyrinth informs a good deal of medieval literary theory (the writings of Geoffrey of Vinsauf and the poetics of Boccaccio, for instance). Yet neither Geoffrey nor Boccaccio mentions the labyrinth explicitly in the discussions in question. How, then, can they be describing a labyrinthine aesthetic? As we saw clearly in Ovid and Virgil, and with strong probability in Prudentius, the Gesta Romanorum, and the Queste del Saint Graal, people writing about labyrinths don't always name them. The ref usal to use the word may be witty, as in Ovid: name a circuitous thing circuitously. It may come from the desire not to confuse an audience by unfamiliar references, as with the Gesta. It may be a matter of keeping the classics and Christianity separate, as perhaps with Prudentius and the Queste. Presumably none of these reasons applies to Geoffrey or Boccaccio. However, it is possible that writers, particularly writers defending ornate secular literature, might avoid the word "laborintus" because of its generally pejorative connotations in the moral contexts reviewed in Chapter 6 , even though the idea of the labyrinth in its full complexity is perfectly acceptable. Geoffrey advocates an exceedingly elaborate "high" style: as Jane Burns has noted, among rhetoricians "the guiding principle for both reading and writing is not Truth but artifice."2 And Boccaccio justifies rhetorical obscurity as good in itself. Now, it is very likely that it was not really as dangerous to defend rhetoric, the high style, and poetic difficulty as medieval theoreticians sometimes pretended; but even so, recriminatory vituperations from antiliterary rednecks might legitimately be expected. Why, Geoffrey and Boccaccio might have asked, provide extra ammunition by pointing out that one was actually recommending the creation of labyrinths of words-perilous, inextricable, error-filled imitations of pagan rather than Christian art? For so those moralists who inveighed against secular fiction might well have interpreted the labyrinth. Moreover, few writers would like to imply that they were intentionally instilling the confusion so of ten associated with labyrinths; perhaps difficult process is one thing, labyrinthine involution quite another (even Geoffrey, master of circumlocution, speaks repeatedly of the need to be clear-to sophisticated readers, of course). Not many people went as far as Eberhard of Germany, whose rhetorical treatise is called Laborintus, a title that provides a fair measure of justification for assuming that an inherently labyrinthine aesthetic might be consciously perceived as such. If the word labyrinth was not of ten used to

2. E. Jane Burns, Arthurian Fictions: Rereading the Vulgate Cycle (Columbus: Miami University/Ohio State University Press, 1985), p. 25. 
describe praiseworthy literature and literary theory in the Middle Ages, in contrast to the honoring of labyrinthine art in classical and early Christian times, then, the common pejorative associations of the word may have played some role in that curious omission. ${ }^{3}$

But my argument does not rely on the conscious use of the labyrinth by authors like Geoffrey and Boccaccio. I propose merely that the idea of the labyrinth is a useful model or analogue for, and codification of, the way much literature was thought to be designed, written, and understood. Consciously or not, many medieval theoreticians saw complex literature as labyrinthine: as highly patterned art, circuitous and ambiguous in design, expression, and experience; relative and convertible; inextricable or impenetrable if badly wrought or if intended for a select few; and teleological in one sense or another: either some new knowledge is to be achieved at the center of the textual maze or the circuitous process itself is beneficial, exercising or relaxing the faculties. In the labyrinthine spirit of duality, difficult literature can be a labyrinth in bono or in malo, depending on what one thinks of labyrinths and literature in general and in particular. Complex literature is none the less labyrinthine even if its writers thought of labyrinths not at all. ${ }^{4}$ If at times in this chapter, in Hans-Georg Gadamer's words, I "understand what the text did not at all intend to say, but [that] which we find expressed in it," I am also treating the labyrinth as an implicit "parallel system" or covert image that may reasonably be extrapolated from a text and used to shed light upon it. ${ }^{5}$

To begin this discussion of verbal labyrinths, consider the description of a labyrinthine literary text in Hugh of Saint Victor's De arca Noe morali (ca. 1125-1130), in a passage that suggests how he thinks writing is, and is not, a labyrinth. Hugh spends four long books explaining the manif old symbolism of the ark, the need for each man to build his own spiritual house of God, the reason why so much labor is involved in the process, and the final symbolism of the ark as container of all human history, all mystery, all faith, existing beyond time in an eternal present. At last, he asks, "What then is this ark, about which we have said so many

3. Although the word labyrinth was of ten avoided where it might have been expected in texts with a high density of labyrinth lexis, the visual image, and thus the principles implied in that design, continued to denote great artistry during the Middle Ages, as we saw in chap. 5 .

4. Cf. Martin Esslin: "A descriptive term applied post factum may be useful even if the people to whom it is applied are unaware of its existence and meaning, provided that such a term is not taken as totally defining the works to which it is applied, but merely as descriptive of certain features which they have in common and which are basic to them": An Anatomy of Drama (New York: Hill \& Wang, 1976), p. 59.

5. See Hans-Georg Gadamer, Truth and Method, trans. Garrett Barden and John Cumming (New York: Seabury Press, 1975), p. 304, and Judson Boyce Allen, The Ethical Poetic, pp. $146-149$. 
things, and in which so many different paths of knowledge are contained? You do not think it is a maze, I hope? For it is not a maze, nor is there toil therein, but rest [Non labyrinthus, nec labor intus, sed requies intus]."6 Hugh's witty etymological disclaimer suggests that he knows very well that his work consists of and enjoins labyrinthine processes. Both the text and the processes of understanding and reform it advocates are long, circuitous, and arduous, potentially as exhausting and bewildering as any inextricable maze. Hugh's extended exegesis is itself loosely labyrinthine in structure: he offers so many perspectives on a biblical text, so many alternative interpretations of each detail, that the "many different paths" create a multicursal hermeneutic maze of staggering complexity and artistry crammed with choices and clues each of which leads to an important center of new knowledge. ${ }^{7}$ But Hugh insists that neither his text nor the work it entails is ultimately labor or a labyrinth, and the implied reasons are revealing: through toil comes eventual rest, and there are no frustrating blind alleys, for each path is fruitful. For Hugh, apparently, true verbal labyrinths-and he takes the word in a strictly pejorative sense-take you nowhere, but his own labyrinthine work brings transcendence of mundane mazes through the perception of stable order from the privileged perspective of eternity. Textual complexity and interpretive multiplicity suggest labyrinths to Hugh, else why would it occur to him that people might think his treatise a labyrinth? His defense is that because his work is not inextricable and profitless like mazes in malo, it is not really a maze. Perhaps, too, he sees the ark as a better image of cosmic complexity than the pagan labyrinth: domus Dei is not domus daedali. ${ }^{8}$ Hugh's comments, then, reflect the inherent labyrinthicity of difficult texts-their complex artistry, their circuitousness, their reliance on the polysemousness that turns one path into many, their convertibility from confusion to order. At the same

6. I use Sr. Penelope's translation, Selected Spiritual Writings (London: Faber, 1962), p. 151 ; see also $P L, 176,679-68$ o.

7. The structural analogy between multicursal maze, allegory, and medieval distinctio (a medieval technique for ordering various interpretations of a key word or concept by listing, and of ten diagramming, the options as branches of a single topic) is implicit elsewhere: Hugh comments, "We set out to talk about one ark, and one thing has so led to another that it seems now we have to speak not of one only, but of four. . . Let us call the first Noah's ark, the second the ark of the Church, the third the ark of wisdom, and the fourth the ark of mother grace. Nevertheless, there is in a certain sense only one ark everywhere. ... The form is one, though the matter is different" (Selected Spiritual Writings, pp. 59-6o).

8. See Didascalicon 6.2 and 6.4 on scripture as domus. In later quotations from the Didascalicon, I follow Jerome Taylor's translation, The Didascalicon of Hugh of Saint Victor: A Medieval Guide to the Arts (New York: Columbia University Press, 1961), here pp. 140-141. I have checked the translation against C. H. Buttimer's Latin edition (Washington, D.C.: Catholic University Press, 1939). 
time, he bows to the common view that good texts should not be called labyrinths because they are not inextricable or impenetrable. So generally were mazes and inextricability linked in the popular imagination that the idea of the labyrinth may inform a good text, but the name should be omitted.

Hugh's comments suggest the relativity or convertibility of the labyrinth: what seems labyrinthine while in process becomes order once labor brings understanding. This is one reason why the labyrinth is a useful model for difficult texts or arguments presenting complex ideas in a circuitous or elaborately articulated order to enhance effective teaching. To the learner or decoder, such a text may seem a labyrinth; to the teacher or encoder, it is well-ordered to convert ignorance to mastery. Knowledge, then, has two faces: the confused, pejoratively labyrinthine face turned to the student as yet ignorant of what may be discovered, and the ordered face delineated by the experience of the labyrinth. As the rota-rosa contains two designs in one figure, so the labyrinth is a dual image of circuitous confusion and concentric circles of order. ${ }^{9}$

In a similar spirit of duality, the labyrinth may be a model both for the literary work as textual product and for the intellectual processes a text implies, from its conception as a text to the choices and difficulties involved in its writing and reception. We are now ready to pursue the analogy more systematically. At the start of his well-known treatise $O n$ Christian Doctrine, Augustine notes that the study of scripture demands "a way of discovering those things which are to be understood, and a way of teaching what we have learned." 10 Regardless of whether literature is didactic or recreational, certain requirements pertain to any considered act of communication: the author/speaker must have discovered something to say (in medieval rhetorical terms, there must be inventio); the chosen material must be appropriately ordered (dispositio or arrangement); and the content must be expressed clearly and, if possible, ele-

9. Concentric circles, the underlying structural basis of most medieval mazes, were often used as a visual teaching device: see John of Garland's stylistic rota Vergilii, "Poetria magistri Johannis anglici de arte prosayca metrica et rithmica," ed. Giovanni Mari, Romanische Forschungen, 13 (1902), 883-965, here 9oo; Ramon Lull's diagrams, several of them printed in Frances A. Yates, "The Art of Ramon Lull," Journal of the Warburg and Cortauld Institutes, 17 (1964), $115^{-173}$, and The Art of Memory (London: Routledge \& Kegan Paul, 1966); Harry Bober, "An Illustrated Medieval Schoolbook of Bede's De Natura Rerum," Journal of the Walters Art Gallery, 19-20 (1956-57), 64-97; and Murdoch, Album of Science, pp. 52-61. Hugh uses the image to suggest divine order in his second treatise on the ark, De arca Noe mystica: God appears within the ark holding a sphere, whose outermost circle shows the heavens and the zodiac; inside is a circle of air, seasons, and the winds; inside that, a map of the world: see Selected Spiritual Writings, pp. 31-32. Rotae of winds, elements, humors, and qualities were common mnemonic devices.

10. Augustine, On Christian Doctrine 1.1 (p. 7). 
gantly (elocutio). ${ }^{11}$ These steps, enumerated in countless classical and medieval rhetorical treatises, are at least potentially labyrinthine; they provide a useful framework for discussing the intellectual activities that go into the creation of texts (and figure in many other contexts as well). We begin with invention, which I interpret fairly loosely to include all the mental processes involved in finding material to write about.

\section{- Labyrinthine Inventio •}

Most often, as medieval theory and practice tell us, authors cull their material from preexisting works - from literary authority (for the poet) or biblical/theological writings (for the religious writer)-rather than from experience: writing about new material was considered too easy to merit serious discussion in an art of poetry. ${ }^{12}$ The best composition, then, involves "invention" in a peculiarly medieval sense; far from being novel, a good subject entails reshaping other people's works or an arduous retracing of steps such as one might experience in a labyrinth. To find and develop this material, to "invent" it, writers normally applied certain procedures: for students of John of Garland (ca. 1 195-ca. 1 272), questions like "where? what? what kind? how? for what purpose?" would be guides to invention; others might search the Aristotelian categories and topics for methods of invention. ${ }^{13}$ Whether authors rely on John, Aristotle, or other guides, they find a bewildering assortment of choices,

11. I use standard medieval rhetorical terms, but one might as easily use the vocabulary of the medieval accessus and speak of labyrinths appropriate to the forma tractandi (manner and style of treating a subject) and the forma tractatus (order and arrangement of parts in a work). The forma tractandi becomes labyrinthine when it involves ambiguity, puns, circumlocutions, etc.; the forma tractatus is labyrinthine when it involves interlaced narrative structures (discussed below), debate structures, theme-and-variations structure of fering choices of points of view on a subject (as in the "Marriage Group" of Chaucer's Canterbury Tales), and so on. Similarly, the forma tractatus is particularly labyrinthine when, in Judson Boyce Allen's words, "the literal ordering of a text's material corresponds exactly to the order of that mental process whereby that material was invented and made significant." In such works as Piers Plowman, Boethius's Consolation of Philosophy, and Sir Gawain and the Green Knight, "meaning must arise out of the dialectic motion through its parts that is the experience of its characters," and "the experience of it is its meaning" (The Ethical Poetic, pp. 92-93). Allen and Minnis (The Medieval Theory of Authorship) devote considerable attention to the forma tractandi or modus agendi and the forma tractatus.

12. See Douglas Kelly, "The Scope of the Treatment of Composition in the Twelf th-and Thirteenth-Century Arts of Poetry," Speculum, 41 (1966), 273, and Geoffrey of Vinsauf's Documentum de modo et arte dictandi et versificandi, sec. 132, in Faral, p. 309. Faral prints the shorter form of the Documentum; the longer version, which discusses how to treat original material, is being edited by Sr. Margaret F. Nims of the Pontifical Institute of Medieval Studies, Toronto.

13. See The Parisiana Poetria of John of Garland, ed. Traugott Lawler (New Haven: Yale University Press, 1974), pp. 8-51; for a general view of methods of invention, see James J. Murphy, Rhetoric in the Middle Ages: A History of Rhetorical Theory from St. Augustine to the Renaissance (Berkeley: University of California Press, 1974). 
a multicursal labyrinth of material and questions to ask about that material. But the mention of Aristotle is particularly significant because "Aristotle's labyrinth" seems to have been a medieval catchphrase in intellectual matters. What exactly did people mean by it?

Aristotelian concordances do not help: the only explicit labyrinth mentioned is "the sculptor's labyrinth," a spiral model used in ornamenting capitals. A peripheral source for the idea might be Simplicius's use of the labyrinth to illustrate Aristotle's concept of infinity as something difficult or impossible to traverse, a meaning consonant with medieval usage of the formula, as we shall see. ${ }^{14}$ But we can do better than that: I would locate Aristotle's labyrinth-or, better yet, labyrinths-not in an Aristotelian passage but in the whole Aristotelian corpus and methodology. For Prudentius, pagan philosophy, and in particular the philosophy of Plato and Aristotle, was a labyrinth; consequently, Aristotle's labyrinth can be simply the study of Aristotelian thought, which is pagan and therefore misleading. But Theodore Prodromos, a Greek writer of the twelf th century, more suggestively fears wandering "in the labyrinth of syllogisms," including the works of Aristotle and Plato: for Theodore it is presumably not pagan philosophy in general but rather logic and dialectic, taught in the west from the twelfth century on largely through the works of Aristotle, that constitute Aristotle's labyrinth. ${ }^{15}$ In the visual arts, diagrams of Aristotelian categories, fallacies, rules for constructing syllogisms, and so on, are complicated and ornate, of fering baffling arrays of choice which, if they do not exactly constitute multicursal labyrinths, bear some resemblance to them. ${ }^{16}$ In literature, John of Salisbury was one of many whose praise of the Topica and De sophisticis elenchis is tempered by awareness of their bewildering difficulties. Thus he condemns "those who follow Aristotle ... in a confusing babel of names and verbs and subtle intricacies [and thereby] blunt the mental faculties of others in their effort to show off their own intellectual capacity," using too much "obscurity" and "involved language." 17 The Posterior Analytics,

14. For Aristotle see Historia animalium 2.1, in Aristotle, Works, ed. J. A. Smith and W. D. Ross (Oxford: Clarendon Press, 1910), vol. 4; for Simplicius, see chap. 3, n. 29 above. The enthymeme, that rhetorical syllogism that rests on probability and hence may easily be false, might also have seemed deceptively labyrinthine.

15. For Prudentius, see chap. 3; for Theodore, In Bareum, $P G, 133,1412$. On the two Analytics, the Topica, and the De sophisticis elenchis, see Murphy, Rhetoric in the Middle Ages, p. 106 and passim. In treating Aristotle's labyrinth of dialectic under "invention," I am thinking more of how one uses dialectic to discover what one wants to write about than of a dialectical method of presenting the material. Obviously, an author can enter Aristotle's labyrinth as inventor and as disposer.

16. See Murdoch, Album of Science, passim. The multicursal maze resembles a tree diagram in offering an extended series of choices, but where the choices in a tree branch out, the choices of a multicursal labyrinth eventually circle inward toward a single goal.

17. John of Salisbury, The Metalogicon 4.3, trans. Daniel D. McGarry (Gloucester, Mass.: Peter Smith, 1971), p. 207. For the Latin text, see Opera omnia, ed. J. A. Giles, 5 vols. (Oxford: J. H. Parker, 1948), 5, 159. 
a standard school-text, is "extremely subtle" and "even more perplexing than the rest," and the Perihermeneias is essential despite, and indeed because of, its difficulty: Aristotle's "thoughts are very subtle," and his "wording is very difficult to understand. However, we should be thankful for both these features, for while the thoughts instruct, the words exercise our minds." 18 Although John does not mention a labyrinth per se, his language reflects the labyrint hine qualities he found in Aristotle's thought and words, and his appreciation of the uses of that difficulty takes us close to a labyrinthine theory of instruction if not to a labyrinthine aesthetic, both of which privilege circuitous process. Medieval consciousness of the difficulties and occasional inextricability of dialectic was keen, as commentaries on the labyrinth in Boethius's Consolation reflect: thus Denis the Carthusian (1402-1471) defines labyrinthine arguments as so complex that entangled readers can neither solve nor abandon them, always returning to the point whence they began: this sort of thing creates yet another conceptual labyrinth, that of oblivion, as Boncompagno da Signa notes. ${ }^{19}$

Humanists such as Erasmus, Milton, and Locke found the scholastic method, with its heavy dependence on Aristotle, labyrinthine in a pejorative sense. Walter of Saint Victor anticipated them, labeling Abelard, Lombard, and the others "the four labyrinths of France," all of them "puffed up by the same Aristotelian spirit."20 More of ten, however, Aristotle's labyrinth connotes laudable complexity accessible only to the elite. Thus Arnulf of Milan (d. 1077), in a charmingly modest prologue to his history of the Milanese archbishops, demurs that he can provide only a simple chronological narrative account: he has never mastered the Quadrivium, and as for the Trivium, "meager wit has narrowed me so that I see only with difficulty the entrance to Aristotle's labyrinth [dialectic?] and the intensely difficult access to the palace of Tully [rhetoric]."21 Much later (ca. 1300), a formulary from Orléans, a university noted for its classicism and later for its legal studies, indicates what a commonplace Aristotle's labyrinth had become: three form letters wish the student "health and easy entry into Aristotle's labyrinth," and if the formula itself does not suggest the value a knowledge of that particular labyrinth was thought to have, the linking of the maze with "the pearl of knowl-

18. Metalogicon 4.6 and 3.4 (pp. 212 and 166); for the Latin, 5, 162 and 130.

19. For Denis, see Enarrationes seu commentaria in V libros . . . de consolatione philosophiae, Opera omnia, vol. 26 (Cologne: Typis Cartusiae S. M. de Pratis, 19o6), p. 424; for Boncompagno, Rhetorica novissima, p. 276.

20. Erasmus, Letter to Dorp (No. 337), in The Correspondence of Erasmus, Collected Works, vol. 3, trans. R. A. B. Mynors and D. F. S. Thomson, annotated by James K. McConica (Toronto: University of Toronto Press, 1976), p. 125; Milton, Paradise Lost 2.561; Locke, Essay Concerning Human Understanding 3.10.9; Walter, PL, 199, 1127. For labyrinths in Paradise Lost, see Diehl, "Into the Maze of Self," 293-296; I would interpret the evidence somewhat differently.

21. Arnulf, $P L, 147,289$. 
edge" in one letter makes it clear that this labyrinth is excellent to master, while sending the letter "in Thesean faith" suggests that mastery is eminently possible. ${ }^{22}$ Aristotle's labyrinth, then, might be dialectic or even the Seven Liberal Arts, given the general intrusion of Aristotelian method into all branches of university curricula. Despite Arnulf's distinction, then, rhetorical invention could well take would-be writers into one or another part of the vast labyrinth of Aristotle's methods and writings, especially once the Rhetoric was translated into Latin by William of Moerbeke in about 1270.

Even people who know their way around Aristotle's labyrinths of topics, categories, and dialectic might find that thinking and writing about difficult intellectual concepts constitute an epistemological labyrinth. Thus Hugh of Saint Victor apologizes that his discussion of human intellectual powers has necessarily created "an inextricable labyrinth" not by "involved words" (rhetorical language), which presumably could have been avoided, but by "obscure matter." 23 And even material not intrinsically labyrinthine may become so when the sheer prof usion of views and alternatives defies order and analysis. Ralph Higden, asked to write a history of the world, faces just this problem of mastering and arranging infinite data and understandably hesitates: "poo toke I hede pat pis matir, as laborintus, Dedalus hous, hap many halkes [recesses] and hurnes [corners], wonderful weies, wyndynges and wrynkelynges, pat wil nouzt be vnwarled [unraveled]. . . . My witt is ful luyte to unwralle pe wrappyinges of so wonder werkes: pe matire is large, writers perynne bep many." 24 Invention, comprehension, and disposition fail when sources are inextricable; a good writer must be a Daedalian master of complexity. Thus invention can involve Thesean adventures through the verbal and conceptual mazes that provide subject matter to write about. ${ }^{25}$ Understanding what is going on in labyrinthine sources is difficult, not least because of the profusion of choices and the circuitous logical processes required.

\section{- Labyrinthine Dispositio •}

Disposition, the ordering of material that constitutes the writer's second task, is at least as labyrinthine as invention: its aim is a brilliantly and effectively structured work of linguistic art; it, too, involves constant

22. Le Formulaire de Tréguier, pp. 16, $20,25$.

23. Hugh, Didascalicon 1.4 (my trans. from Buttimer, p. 10).

24. Ralph Higden, Polychronicon 1.7; I cite Trevisa's expanded translation; Higden glosses the labyrinth "inextricabilem . . . intricationem" $-1,8-9$.

25. Authority constitutes a multicursal labyrinth through which a medieval writer traces his own characteristic path, following now this source, now that, and periodically branching out on his own-a posture that Chaucer typically adopts, most clearly in Troilus and Criseyde. 
choice; and, according to rhetorical handbooks, it of ten deploys a circuitously "artificial" order that circles back and forth in time, as in the Queste del Saint Graal. Ironically, although the labyrinth is, as I will argue, the most appropriate analogy to poetic ordering, there is little explicit mention of mazes in this context, perhaps because few medieval authors want to recommend weaving confusion by imitating a labyrinth, even with contrary precedent in Jerome, Ennodius, and Sidonius. After all, as Thomas Aquinas notes, "Sapientis est ordinare [it is the function of the wise man to order]," and although the idea of the labyrinth includes order, popular medieval connotations of the word do not. Nor do labyrinths necessarily of fer the "better and more certain path" detected by an early commentator in Geoffrey of Vinsauf's Poetria nova. ${ }^{26}$ But if models for the poetic process provide few explicit labyrinths, many highlight one or another characteristic in bono of the labyrinth, and if we put the models together, the resulting composite image points to an implicitly labyrinthine aesthetic. It is worth noting that disposition was an extremely important aspect of medieval poetry, even though the subject is not extensively discussed in many rhetorical treatises, which focus more heavily on elocutio.or expression. Douglas Kelly, Jane Baltzell, and others have emphasized that medieval theorists repeatedly advocated having a clear idea of what the poem was to accomplish, how it could best be structured to that end, and how the general plan should determine subsequent choices of style, ornament, and so on; and Edgar de Bruyne comments that preaching manuals in particular recommend "composition of incredible complexity, the theoretical simplicity and verbal virtuosity of which astonish us" - an opinion with which any student of medieval literature must concur. ${ }^{27}$ If God ordered all things by number, measure, and weight, so should the human artifex, and ordering a text is no exception.

Medieval authors discussed dispositio in interesting and suggestive ways. In many accessus or academic prologues, the concept of ordinatio is addressed under the headings "formal cause" (the dual formal causes are the forma tractandi or method of treatment and the forma tractatus or arrangement of sections) and "final cause" (the end toward which the

26. I quote Thomas from A. J. Minnis, Medieval Theory of Authorship, p. 146. For Geoffrey's commentator, see Marjorie Curry Woods, An Early Commentary on the Poetria Nova of Geoffrey of Vinsauf (New York: Garland, 1985), pp. 18-19. Both Minnis and Allen (The Ethical Poetic) devote much attention to medieval discussions of disposition and the importance of the reader's understanding of the author's ordering principles.

27. Kelly, Speculum, 41, 261-278; Jane Baltzell, "Rhetorical 'Amplification' and 'Abbreviation' and the Structure of Medieval Narrative," Pacific Coast Philology, 2 (1967), 32-39; Edgar de Bruyne, The Esthetics of the Middle Ages, trans. Eileen B. Hennessy (New York: Frederick Ungar, 1969), p. 203. Many scholars in the earlier part of this century believed that because dispositio did not receive lengthy explicit treatment in rhetorical handbooks, it was not important to poets; this view is now largely discarded. 
writing is directed-its perceived utility for its readers). Thus, commenting on Aristotle's Ethics, Aquinas distinguishes between two kinds of order. As A. J. Minnis summarizes, "One kind of order is that which the parts of a whole have among themselves. For example, the parts of a house are mutually ordered to each other. Another kind of order is that of things to an end." 28 Order is dual: there is an intrinsic and internal order of the thing itself as an artifact, and there is the order whereby the artifact is constructed for a purpose, thereby embodying a teleological process. Perhaps the best image of this dual order is the labyrinth, simultaneously depicting artifact and process.

Thus it is not surprising that rhetorical treatises illustrate disposition with metaphors that reflect one or more aspects of the text/labyrinth-asartifact or the text/labyrinth-as-process. One such metaphor is building a house, which alludes simultaneously to process and to the resulting artifact. Other common metaphors describe process only: the following of a path, or circling around a certain point. Yet another metaphor, more common in twentieth-century analyses of medieval writing than in medieval works themselves, is the interlace, based in part on the idea of the text as a weaving together of words. All these metaphors merit further discussion in the quest for an implicit labyrinthine aesthetic.

Comparisons of house to literary work are based on the fact that both artifacts demand disposition, actual construction, and elegant decoration. The best-known example is from Geoffrey of Vinsauf's Poetria nova:

If a man has a house [domum] to build, his impetuous hand does not rush into action. The measuring line of his mind first lays out the work, and he mentally outlines the successive steps in definite order. The mind's hand shapes the entire house before the body's hand builds it. Its mode of being is archetypal before it is actual. . . . [Thus, in writing poetry] let the mind's interior compass first circle $[$ circinus ... praecircinet $]$ the whole extent of the material. $\left(\mathrm{N} 16-17 / \mathrm{F}_{198}-199\right)^{29}$

28. Minnis, Medieval Theory of Authorship, p. 147.

29. On the house-poem analogy, see Charland, p. 194, and Ernest Gallo, The Poetria Nova and Its Sources in Early Rhetorical Doctrine (The Hague: Mouton, 1971), p. 137; for the three parts of building, see Isidore, Etymologiae 19.9, following a passage in praise of Daedalus. The Poetria nova (ca. 1210) is by far the most popular rhetorical handbook; surviving in more than two hundred manuscripts, it enjoyed considerable commentarial attention into the sixteenth and seventeenth centuries: see Gallo, "The Poetria Nova of Geoffrey of Vinsauf," in James J. Murphy, Medieval Eloquence: Studies in the Theory and Practice of Medieval Rhetoric (Berkeley: University of California Press, 1978), p. 52, and Woods, Early Commentary on the Poetria Nova, pp. xvii-xxii.

I generally quote from Poetria nova, trans. Margaret F. Nims (Toronto: Pontifical Institute of Medieval Studies, 1967), with bracketed Latin from Faral's edition ( pp. 194-262); parenthetical references are to those editions. 
The passage suggests an analogy that some of Geoffrey's readers may well have noticed: if architect is to house as poet is to poem, if the greatest architect is Daedalus and his greatest work the labyrinth, then great literature too may appropriately be labyrinthine in artistry, as Ezekiel's prophecy was to Jerome or as the scriptures in general were to Rudolf of Saint Trond (1070-1138). ${ }^{30}$ The presence of aristocratic labyrinth-buildings in the Middle Ages might have facilitated the analogy. That Geoffrey's text-house is designed with compasses goes still further to evoke the image of the labyrinth, that circular domus traced with compasses, emblem of human and divine art in cathedrals. ${ }^{31}$ Implicitly, then, a great poem is as complex and brilliantly structured as a labyrinth.

Geoffrey's poem-domus involves a circling process. We shall see more about the circling/circuitousness essential to maze and fine poem under elocutio, but for the moment consider two accounts of the didactic and aesthetic importance of a winding or circling movement in texts seen whole, as artifact. First, Peter of Cornwall praises a sermon by Gilbert Foliot for its circuitous design: "It ran backwards and forwards on its path from its starting-point back to the same starting-point." 32 The pattern described here is not merely a path: it is best imagined as the circuitous path of a maze. For Robert of Basevorn, "The more the end [of a good sermon] is like the beginning, so much the more subtly and elegantly does it end." 33 Again, the labyrinth allows for just such a conjunction of beginning and ending: "You seem to begin where you ended and to end where you began," Boethius says while accusing Philosophy of weaving labyrinths; ${ }^{34}$ and this circular construction is a familiar feature in Pearl, Sir Gawain and the Green Knight, and Piers Plowman. This sort of circular structure-labyrinthine structure-is both beautiful and didactically effective, as Augustine argues in the De magistro.

If the image of a house plotted by compasses suggests a labyrinth-asartifact containing a labyrinth-as-process in the form of a path circling back and forth, the idea of following a path constitutes another common

30. See chap. 3 for Jerome; Rudolf, Vita sancti Lietberti, $P L, 146,1451$. Hugh of Saint Victor makes much of the analogy between sacred scripture and a well-wrought domus, but given his predilection for direct, uncomplicated, noncircuitous statement, his scriptural domus is presumably no more a labyrinth than his ark is: see Didascalicon 6.4 (Taylor, pp. $140-141$ ).

31. I do not mean to imply that all circular structures are labyrinths, but rather that circular structures are potentially labyrinthine, especially if they involve changes of direction, backward and forward movement, and so on, as poetic order does for Geoffrey.

Geoffrey's metaphor may also suggest a comparison of the poet-architect to God, who circumscribed the cosmos with compasses and logos.

32. Quoted by A. C. Spearing, Criticism and Medieval Poetry (London: Edward Arnold, $1964)$, p. 75 .

33. Robert of Basevorn, The Form of Preaching (1322), trans. James J. Murphy in Three Medieval Rhetorical Arts, ed. Murphy (Berkeley: University of California Press, 1971), p. 200; for the Latin text, see Charland, p. 310.

34. Boethius, Consolation of Philosophy $3 p_{1} 2$ (Green, p. 72). 
metaphor for poetic composition. This metaphor, stressing teleology rather than the shaping of an artifact, reflects the linearity, be it unicursal or multicursal, of composition, writing, and even reading. The image is related to the use of "ploughing" for writing and "furrow" for a line of verse, ${ }^{35}$ but let us turn again to Geoffrey for a full exposition in the context of natural and artificial order in poetry:

The material's order may follow two possible courses: at one time it advances along the pathway [limite nititur: "labors on the narrow path"] of art, at another it travels the smooth road [sequitur stratam: "follows the open road"] of nature. Nature's smooth [linea: "straight"] road points the way when "things" and "words" follow the same sequence, and the order of discourse does not depart from the order of occurrence. The poem follows the pathway of art if a more effective order presents first what was later in time, and defers the appearance of what was actually earlier. Now, when the natural order is thus transposed, later events incur no censure by their early appearance, nor do early events by their late introduction. . . . Deft artistry inverts [vertit: "turns"] things in such a way that it does not pervert them [non pervertat].... The order of art is more elegant than natural [recto: "direct"] order, and in excellence far ahead, even though it puts the last things first. $\left(\mathrm{N}_{1} 8-19 / \mathrm{F}_{200}\right)^{36}$

In ordering a poem, authors face a bivium or, if they decide to follow both natural and artificial order at various points, a series of bivia, whose goal is excellent structure. The moral bivia with which we are familiar, choices between good and bad paths, take on aesthetic trappings: the easy wide road is clear ("manif esta" for the commentator), direct, and generally accessible to writer and reader alike. In contrast, the narrow artistic path that is "subtle and known to few" (the commentator's words) entails an arduous artistic struggle. When Arnulf of Milan decided to follow natural chronological order because he found the entry to Aristotle's labyrinth too narrow, he may have had in mind something like this; Geoffrey's path of art, rhetorically effective and elegant, is also more labyrinthine, in that it does not move directly from point $A$ to point $B$ in a straight line like natural order but rather winds circuitously back and forth in time like the narrative line of the Queste del Saint Graal or the path of a maze, whether unicursal or multicursal. Artificial order, in short, creates a digressive and meandering labyrinth for writers as they write and readers as they read. The mazy nature of this order is en-

35. Ernst Robert Curtius, European Literature and the Latin Middle Ages, trans. Willard R. Trask (New York: Harper \& Row, 1953), pp. 313-314.

36. Cf. Jerome's assumption that putting first things last is a labyrinthine order of proceeding and Ennodius's linking of labyrinth, poem, and path.

Bracketed translations in the quotation reflect shades of meaning detected by Geof frey's early commentator: Woods, Early Commentary on the Poetria Nova, pp. 22-25. 
hanced by Geoffrey's next comments, which suggest a multicursal pattern: "The first branch of order has no of fshoots; the second is prolific: from its marvelous stock, bough branches out into boughs, the single shoot into many, the one into eight. The air in this region of art may seem murky and the pathway rugged, the doors locked and the theory itself entangled with knots" ( $\left.\mathrm{N}_{19} / \mathrm{F}_{200}\right)$. There are several things to be noted here. First, this cluster of images (paths, branchings, darkness, knots, keys) frequently attends the labyrinth as emblem of difficulty. Since Geoffrey proceeds to give examples of artificial order from the story of Minos, Scylla, and Androgeos, the prelude to Ovid's labyrinth story but a far simpler episode to use as an illustration, it is conceivable that the labyrinth was consciously or subconsciously in Geoffrey's mind as he wrote on artificial order. ${ }^{37}$ More important, however, is the suggestion, picked up by Geoffrey's early commentator, that artificial order is not merely circuitous but also "multiplex" in comparison to the "simplex" natural order. ${ }^{38}$ The commentator stresses the obscurity and complexity of the subject, and perhaps for him "simplex" and "multiplex" refer only to whether an author chooses natural or artificial order, Geoffrey's nominal, and probably real, topic. But, as Kelly has shown, these terms have a long rhetorical history and suggest something far more complicated: an author's decision to follow the comparatively simple course of telling one story, however artificially it may be ordered, or many. ${ }^{39}$ Artificial order is itself a kind of circuitous labyrinth; when artificial order is applied to "multiplex" narrative, something even more labyrinthine results.

Kelly distinguishes two major kinds of multiple narrative: (1) a complex story linking many disparate elements and episodes that are united by some feature like a common protagonist (Yvain, the Divine Comedy, Sir Gawain and the Green Knight); (2) interlaced stories like the French cyclic romances, their complexity augmented by the sheer number of linked but divergent episodes that may have little in common. The first kind of narrative line is, I would argue, analogous to a unicursal labyrinthcomplicated, circuitous, full of turnings ( probably caref ully highlighted) from one episode to another; the second is like a multicursal maze, for the narrative line not only twists and turns but also chooses completely different (and carefully highlighted) paths from time to time. The Queste del Saint Graal is structurally a multicursal labyrinth in this narrative sense,

37. Geoffrey may also have chosen the story because the Cretan myth as a whole was sometimes seen as representative of all poetic fictions and hence might appropriately figure in a general introduction to the writing of poetry: see Pseudo-Bernard Silvester, J\&J, p. 37 .

38. Woods, Early Commentary on the Poetria Nova, pp. 24-27.

39. See Douglas Kelly, "The Source and Meaning of Conjointure in Chrétien's Erec 14," Viator, 1 (1970), 179-200. 
for we turn from Galahad to Gawain to Lancelot to Perceval as "li contes" prescribes, even though, as interlaced narrative goes, the Queste is not particularly ornate, and even though the characters' progress may, as we have seen, be a course through every kind of maze; the labyrinths in the text complement the labyrinth of the text. What Kelly describes as "gliding junctures," subtle transitions from one episode to another, characterize multiple narrative of the first sort-in labyrinthine terms, there are turns and redirections rather than new paths. But multiple narrative of the second sort contains "open junctures," carefully marked choices to pursue a completely different course among the ambages that present themselves. ${ }^{40}$ One major reason for these marked junctures, of course, is to weave disparate material together into an artistic whole, as the turnings of either form of narrative-maze noticeably define its complex pattern.

To summarize the discussion of disposition so far, then, artistic ordering inherently, if not explicitly, resembles the labyrinth, paramount emblem of artificial order. Geoffrey's direct road of natural order, going straight to the point in a manner that can be followed by anyone, is not labyrinthine at all; it is simply a path, in structure if not in expression the shortest distance between two points. But artificial order is truly labyrinthine. For its creator, it involves multicursal choices of methods and narrative sequence; for its reader, it is circuitous and convoluted. These winding complex narratives resemble unicursal or multicursal mazes in design depending on whether the discourse of fers a single guiding thread ("simplex" narrative) or a choice of many ("multiplex"). Whether or not medieval disposers thought of labyrinths as they constructed or theorized about their Daedalian artifacts, the ordering process and consequent pattern of an aesthetically satisfying poem are remarkably like the construction and design of a labyrinth, which is, after all, a well-built circular house full of circuitous and sometimes competing paths. Whether Geoffrey had the labyrinth in mind or not, his images for the construction of poetry define the medieval labyrinth.

One more metaphor for disposition must be considered here, although it does not appear in rhetorical handbooks: the interlace, of ten used by modern scholars as a model for medieval narrative structure. ${ }^{41}$ Interlace is a modern term for that complex, interwoven pattern of fo-

4o. Kelly also discusses the common use of ambages to describe the circuitous process of medieval multiple narrative.

41. E.g., Rosemund Tuve, Allegorical Imagery: Some Medieval Books and Their Posterity (Princeton: Princeton University Press, 1966), pp. 359-37o; John Leyerle, "The Interlace Structure of Beowulf," UTQ, 37 (1967), 1-17; Eugène Vinaver, The Rise of Romance; Susanna Greer Fein, "Thomas Malory and La Queste del Saint Graal," UTQ, 46 (1977), 21 5-240. Fernand Lot first applied "interlace" to romance in 1918; on French interlace studies, see Fein, 216-217. 
liage, zoomorphs, and paths that ornaments medieval art from AngloSaxon times through the thirteenth and fourteenth centuries. There are numerous literary analogues to the interlace structure seen in the visual arts. Interlace may be verbal, as in macaronic texts, the writings of $\mathrm{Al}$ cuin and Aldhelm, and the "finely locked words laced together" of the troubadours; it may be narrative and structural, as in medieval romance and Spenser, where one strand of the narrative is followed until another is picked up and then another, with the story often returning to the first strand not where it was abandoned but at some further point that can be better understood thanks to the intervening segments of narrative. ${ }^{42}$ Sometimes literary interlace is thematic and sometimes pictorial, as in $L a$ Queste del Saint Graal, where, as Susanna Fein argues, "through a narrative interweaving of different knights' movements and through much descriptive detail [the author] gradually builds a distinct maze-like image of paths within a forest ... [a] pictorial interlace." 43 Of ten varieties of interlace combine: thus, as Fein shows, the pictorial interlace of the Queste becomes thematic by reflecting the meaning of visual interlace for the Cistercians, for whom "inhabited scrolls frequently symbolized the struggles of man against the vices and complexities of this world." 44

Writings on the aesthetic of the interlace have taught us a good deal about how many medieval artists and writers saw their work as ordered complexity, multiplicity in unity, an array of seemingly disparate but ultimately interconnected elements; and interlace studies confirm the importance and immense variety of artificial orders in literatureorders where the effective presentation of material demands something other than chronological narrative because the patterning of events is far more important than temporal sequence. Based on "an understanding of the great aesthetic possibilities of digression and recurrence," interlace emphasizes overall design rather than individual linear history, with the result that, in Eugène Vinaver's words, "everything that happens remains present, firmly fixed in the mind, as if the mind's eye could absorb simultaneously all the scattered fragments of the theme, in the same way as our vision can absorb the development of a motif along the entire length of an interlaced ornament." 45 Or, one might add, as someone above the labyrinth sees the integrity and symmetry of its exquisite design in one glance.

42. For stylistic interlace, see Leyerle, UTQ, 37 (1967), 4-5, and Linda M. Paterson, The Troubadours and Eloquence (Oxf ord: Clarendon Press, 1975), 91-98 and passim; for narrative and structural interlace, see Vinaver, Tuve, Fein, and Kelly (Viator, 1).

43. Fein, 217 ; Leyerle also discusses thematic interlace.

44. Fein, 221.

45. Vinaver, pp. $9^{2}$ and 83 . For an argument that the premise of many interlace studies - the existence of a master designer who plots the whole complex scheme-is untenable, at least in the French cyclic romances, see Burns, Arthurian Fictions, pp. 12 and $82-84$. 
But if the interlace is a useful model for the disposition of medieval poetry, one justified by a mass of evidence in the visual arts, I would argue that the labyrinth is an even more useful and inclusive model. In fact, as I will suggest, the interlace is best considered as a partial labyrinth. True, the two models are similar in many respects: both are interwoven, textus, like poetry itself. ${ }^{46}$ Both incorporate digressions and errores-wanderings, delays, moral failings, all essential qualities in romance, as Patricia Parker has shown-and exhibit what Vinaver calls an "excess of constructive subtlety" so that they serve as excellent mirrors of universal complexity. ${ }^{47}$ If interlace in the visual arts is sometimes geometrical and sometimes composed of plants and animals, the labyrinth, most of ten geometrical, can also be perceived as involving foliate forms: Nonius Marcellus glosses maeander as "a kind of picture similar to the designs of labyrinths, hindered by tendrils [claviculis]." 48 The two terms are associated in literature in at least one important context: Jean de Meun's and Chaucer's translations of Boethius' "Ludisne... me inextricabilem labyrinthum rationibus texens":

Jean de Meun: "You mock me," I said, "or you play or you deceive me by weaving me with your reasonings the house of Daedalus so interlaced [entrelacié] that one knows not how to undo it ... [and you have used] proofs and interlaced arguments."

Chaucer: "Scornestow me," quod I, "or elles, pleyestow or disseyvistow me, that hast so woven me with thi resouns the hous of Didalus, so entrelaced that it is unable to ben unlaced ... [by using] proeves in cercles." 49

46. On textus, see Leyerle, UTQ, 37 (1967), 4, and Brian Stock, "Medieval Literacy, Linguistic Theory, and Social Organization," $N L H, 16(1984-85), 21$. Poetry is of ten seen as woven: cf. Boccaccio, De genealogia 14.7. So too is the labyrinth: see Boethius, De consolatione 3p1 2; Aeneid 5.589; Sidonius, Epistolae 9.13.

Donald R. Howard (The Idea of the Canterbury Tales, pp. 327-329) briefly compares maze and interlace: both involve turnings and both "express conf usion and puzzlement; they symbolize the world"- a valid but, in my view, overly limited conclusion in that both maze and interlace suggest order as well as chaos. Howard also notes that mazes, unlike interlaces, have a beginning and an end; but I would not agree that "the interlace was visual, the labyrinth tactile."

47. Parker, Inescapable Romance: Studies in the Poetics of a Mode (Princeton: Princeton University Press, 1979), pp. 4-25 and passim; Vinaver, p. 77. Parker's discussion of Ariosto is particularly interesting in this context.

48. On the two types of interlace, see Vinaver, p. 78; for Nonius, De conpendiosa doctrina, p. 203. Geometrical interlace in art could be considered a multicursal version of the diagrammatic maze (perhaps the first medieval attempt to design such a thing?), with natural interlace a version of the garden maze or the labyrinthine forest.

49. Jean's translation is edited by V. L. Dedeck-Héry, $M S, 14\left(195^{2}\right), 165^{-275}$; the quotation is from p. 23o. For Chaucer's translation, see Riverside Chaucer, pp. 438-439 (ll. 154-157, 182). Minnis established Chaucer's indebtedness to Jean and to Nicholas Trevet's commentary: see "Aspects of the Medieval French and English Traditions of the De Consolatione Philosophiae," in Boethius: His Life, Thought, and Influence, ed. Margaret Gibson (Oxford: Basil Blackwell, 1981), pp. $3^{12-361 . ~ T h e ~ p i c t u r e ~ i s ~ f l e s h e d ~ o u t ~ b y ~ M a r k ~ J . ~}$ 
For Jean as for Chaucer, who follows his translation, labyrinths include interlacings. For us and for medieval people, then, interlace and labyrinth are related designs, and modern interlace studies of ten use the image of the maze to explain what they mean by interlace, as Fein does in the passage quoted above. ${ }^{50}$

With all these common features, why is the labyrinth a better, fuller paradigm for medieval literary structure? First, the labyrinth is richer and more comprehensive in formal implication than interlace, and it corresponds more closely to the workings of an actual text. Vinaver and others use interlace to describe the complex narrative pattern of romance, where stories are inseparably entangled, and note that both romance and interlace have in some respects "no beginning, no end, and above all no center-no "means of guidance." 51 Now, this is all very suggestive, but it is not strictly true. Like labyrinths, and unlike interlace, romances and other writings $d o$ have beginnings and ends, of ten very neatly linked (even "unfinished" poems have an end to the text). Narrative literature, like labyrinths and unlike interlace, usually has a centera dominant hero, a central place, thematic centers that may take the form of images. And narrative always has guidance, if not in explicit authorial commentary and thematic statement, then in the thread of the text itself: by disposition, amplification and abbreviation, and narrative line, the author defines a start, a path, and a finish, which, as Vinaver rightly notes, interlace does not. Since labyrinths by definition provide these things, they are a closer analogue to poetic texts: both mazes and texts have beginnings and endings, centers and guiding paths. Interlace does very well as a model for the inner workings of a complex poem, in which characters, themes, and audience are entangled and confused until a pattern emerges, or at least the end is reached, but the labyrinth accounts for both the inner workings and the shape of the whole. The interlace is a brilliant model for "multiplex" romances that interweave the stories of many knights-indeed, this is really the model's most appropriate use-but a diagram of paths through a multicursal labyrinth does just as well, and the unicursal labyrinth is a better model for the majority of medieval narratives, which deal with one major char-

Gleason: "Nicholas Trevet, Boethius, Boccaccio: Contexts of Cosmic Love in Troilus, Book III," ME H, 15 (1987), 161-188, and by Gleason and Minnis in The Medieval Boethius: Studies in the Vernacular Translations of De Consolatione Philosophiae, ed. A. J. Minnis (Cambridge: D. S. Brewer, 1987).

50. See also Vinaver, pp. 69 and $77 n$., and C. S. Lewis, The Discarded Image: An Introduction to Medieval and Renaissance Literature (Cambridge: Cambridge University Press, 1964), p. 194, treating interlaced narrative as an example of the medieval "love of the labyrinthine."

51. Vinaver, p. 69 . 
acter's wanderings. If interlace is a fruitful model, a useful embodiment of the medieval aesthetic of complexity, that is because interlace describes the middle sections of a multicursal labyrinth; the full medieval idea of the labyrinth provides a still more accurate model, a better guide, and a richer concept. Moreover, the labyrinth is the best model for one intriguing aspect of much medieval poetry: it incorporates both linearity (movement from A to B, from beginning to end, from birth to death) and circularity (repetition, possibly with variation; the representation of cycles, narrative, structural, and thematic-seasonal, liturgical, historical). This perfect synthesis of linearity and circularity constitutes one of the most significant features of much labyrinthine poetry and poetic theory.

In addition to being a better model for medieval narrative on purely structural grounds, the labyrinth is also more likely to have been a conscious model, for, as we have seen, it has a rich literary tradition in itself and in connection with poetic process and achievement. In almost every description of the labyrinth from classical antiquity onward, error is an explicit characteristic of the maze but not necessarily of interlace, which has far less extensive a literary history. Moreover, the labyrinth is repeatedly seen as the most illustrious example of sublimely complicated artistry and hence an apt metaphor for magnificent poetry. Symbolism we must read into the interlace pattern is thus demonstrably present in the history of the maze, so that while Vinaver, Leyerle, and others make a good case for the medieval perception of an analogy between interlace and poetry, the case is even stronger for the labyrinth as a conscious medieval model for literature.

\section{- Labyrinthine Elocutio •}

We have now seen how the idea of the labyrinth serves as a model for invention and disposition-how it is explicitly used as a metaphor for various inventive processes and how it covertly underlies and unifies common metaphors for disposition, which merge into the image of a circling if sometimes bifurcated path through a well-crafted domus. So too with the third part of writing, elocutio or expression, through which literary design is implemented and ornamented with words. In disposition, the writer's path requires a choice between artificial and natural order; in elocution, as in a multicursal maze, authors confront another crucial bivium, the choice between amplification or abbreviation of their material, both courses full of labor for the poet-traveler. Given the medieval predilection for poetry that reshapes old stories by altering narrative order and infusing new significance, both roads must be followed from time to time: as Geoffrey's Documentum states, one way to cast a 
story freshly is "not to delay where others delay, but where they delay, let us go quickly, and where they go quickly, let us make delays." 52 However, rhetorical handbooks emphasize the delaying tactics of amplification as the best means to give received material a novel slant. This emphasis on amplification suggests another way medieval rhetoric is labyrinthine: both mazes and amplification expand a given idea or pattern, and both involve circuitous delays that cover far more territory than strictly necessary to get from A to B. Both, too, add complexity to a path that might otherwise be artlessly direct, like natural order. Artificial order and amplification go hand in hand as artistic and enlightening complications that make us shift directions and see things in unusual perspectives and revealing close-up.

Analogies between amplificatory techniques and labyrinths emerge in the names and descriptions of the tropes (significantly, "turns"), the figures of speech and thought used in amplification. ${ }^{53}$ Repetition (interpretatio, expolitio) "take[s] up again in other words what has already been said" (N24/F204), thus circling back over the same ground as one may do in a maze. Circumlocution (periphrasis, circuitio, circuitus eloquendi) is essentially labyrinthine, and Geof frey's comments point the resemblance: "Do not unveil the thing fully but suggest it by hints. Do not let your words move straight onward through the subject, but, circling it, take a long and winding path [ambagibus] around what you were going to say briefly" ( $\left.\mathrm{N}_{24} / \mathrm{F}_{204}\right)$. Apostrophe is labyrinthine in effect as a "mode of delay. By it you may cause the subject to linger on its way, and in it you may stroll an hour" (N25/F205). Personification too "lengthen[s] our route" $\left(\mathrm{N}_{32} / \mathrm{F}_{21} 1\right)$, but digression-a structural characteristic of the maze-is far more interesting. "If it is desirable to amplify the treatise yet more fully, go outside the bounds of the subject and withdraw from it a little. ... A kind of digression is made when I turn aside from the material at hand, bringing in first what is actually remote and altering the natural order. For sometimes, as I advance along the way, I leave the middle of the road, and with a kind of leap I fly of $f$ to the side, as it were; then I return to the point whence I had digressed" (N35/F213). Geoff rey's prose Documentum clarifies that he is talking about two different kinds of digression: (1) moving from one part of the primary matter to another, and (2) jumping from the story to quite different material. Commentaries divide the second category into the more common poetic

52. Section 133 (Faral, p. 309).

53. Although Geoffrey, like many rhetoricians, generally discusses the tropes as they would be used within sentences, there is little doubt that these ornaments were adapted to much larger narrative structures: see Kelly, "The Source and Meaning of Conjointure"; Burns, Arthurian Fictions, p. 77; and, for an extended discussion, Ihle, Malory's Grail Quest, which argues that the Queste amplifies, using interpretatio, circumlocutio, and digressio extensively, whereas Malory abbreviates. 
variety-passing to a related subject, dropping it, and returning to the main path-and the less common sort, in which a radical change in subject is gradually related to the main narrative. ${ }^{54}$ Such digressions are labyrinthine not only in their circuitousness but also in moving into apparent irrelevancies that prove instructive, just as a maze seems to move away from the goal only to approach it more nearly. Augustine treats the pedagogical uses of apparent digression (see Chapter 3 above), and medieval digression, properly controlled, has exactly the same labyrinthine utility, especially in sermons, as Robert of Basevorn notes, adding that when one wishes to teach, the "curiosior" kind of digression-the more artistic sort-is less useful than the "manifestior" or clearer sort. ${ }^{55}$ The more didactic one's intent, the less digressions should rely on the hearer's ingenuity to supply relevance, and vice versa. A preacher must be a clear guide to labyrinths, but a poet may create labyrinths for readers to delight in.

Other rhetorical ornaments have labyrinthine implications: dubitatio, in which one hesitates between this alternative and that, mimicking hesitation at the bivia of multicursal mazes; occupatio, in which an author sketches the path not taken as if filling in untrodden parts of a multicursal maze; and complexio, when a series of phrases or sentences (or, perhaps, an episode or a whole work) begin and end in the same manner. Even polishing one's style-revising, retreading the same path-involves a kind of labyrinthine development, as Geoffrey describes it: "With unflagging energy I turn now in one direction, now in another, and I adorn the subject now with one figure, now with another. I do not turn it over in my mind once only; rather I reconsider it many times. At last the active mind, when it has completed its circuit, chooses one form out of many. ... As I revolve the subject, I evolve it more" (N86-87/F257). Such are the difficulties of the rhetorician's work and of his finished creation, to which Eberhard and his commentator may well have been alluding by entitling his treatise Laborintus and glossing that title "laborem habens intus."

\section{- Difficult Process •}

By now it should be clear that the medieval aesthetic features a predilection for difficulty, complexity, ornateness, circuitousness, artificiality-all qualities associated with the labyrinth. This love of difficulty is

54. See Faral, p. 274, and Marjorie Curry Woods, "Poetic Digression and the Interpretation of Medieval Literary Texts," Acta Conventus Neo-Latini Sanctiandreani, ed. I. D. McFarlane, Medieval and Renaissance Texts and Studies, 37 (Binghamton, N.Y.: MRTS, 1986), 617-626.

55. Charland, pp. 297-298. 
manifested in many ways, not simply by a fondness for artificial order or elegant digression or elaborate amplification. In art, the interlace pattern is popular; in architecture, complicated sculptural programs; in music, increasingly complex polyphonic and rhythmic intricacies. ${ }^{56}$ Poetry and romance employ complex or multiplex narrative, the verbal obscurity and stanzaic elaboration of the troubadours, amazing feats of versification as in the songs of Machaut's Remède de Fortune or the anonymous English Pearl. ${ }^{57}$ Difficulty is artistically valuable in itself, as Geoffrey suggests when he praises the reworking of existing stories by noting, "the more difficult, the more praiseworthy." 58

But difficulty offers more than aesthetic pleasure for the cognoscenti: it also has practical educational benefits, or so many writers claimed. The uses of difficulty were appreciated as early as Aristotle's Rhetoric, which argues that metaphors, puns, and riddles give pleasure because one learns something new and surprising from them, and Augustine notes succinctly that "what is sought with difficulty is discovered with more pleasure." 59 Sacred texts are of ten fraught with difficulties whose penetration brings profit as well as pleasure: "The obscurity itself of the divine and wholesome writings was a part of a kind of eloquence through which our understandings should be benefited not only by the discovery of what lies hidden but also by exercise." 60 Difficulty even stimulates the memory: as Boccaccio notes, "Whatever is got at the cost of a little labor is both more pleasing and more carefully observed than that which gets to the reader's mind of itself." 61 The love of difficulty, probably common to intelligent people in every culture, did not go unchallenged, of course, and it is worthwhile to look selectively at a literary debate that raged through much of the Middle Ages. Boccaccio may

56. On music, see Albert Seay, Music in the Medieval World, $2 \mathrm{~d}$ ed. (Englewood Cliffs, N.J.: Prentice-Hall, 1975).

57. See Paterson, The Troubadours and Eloquence; Guillaume de Machaut, Oeuvres, ed. Ernest Hoepff ner, vol. 2 (Paris: SATF, 1911), and commentary by William Calin, A Poet at the Fountain: Essays on the Narrative Verse of Guillaume de Machaut (Lexington: University Press of Kentucky, 1974), pp. 70-72; and Pearl, ed. E. V. Gordon (Oxford: Clarendon Press, 1953), Appendix 1.

58. Geoffrey, Documentum, Faral, p. 309 .

59. Aristotle, Rhetoric 3.1 1, trans. W. Rhys Roberts (New York: Modern Library, 1954; originally published in the Oxford Aristotle), pp. 190-193; Augustine, On Christian Doctrine 2.8 (13), p. 38.

6o. Augustine, On Christian Doctrine 4.9, p. 123 . In like spirit, Alexander of Hales and Saint Bonaventure mention the benefits to be derived from the fact that scripture's mode of proceeding is "multiplex" even though a simpler "uniform mode" might be thought better at conveying information-see Minnis, Medieval Theory of Authorship, pp. 126-127.

61. De genealogia 15.12, in Boccaccio on Poetry, p. 136. Following parenthetical references are to De genealogia 14.12 in Osgood's translation $(\mathrm{O})$ and Jeremiah Reedy's edition $(\mathrm{R})$, Boccaccio in Defence of Poetry: Genealogiae Deorum Gentilium Liber XIV, Toronto Medieval Latin Texts (Toronto: Pontifical Institute of Medieval Studies, 1978). 
serve as spokesman for defenders of difficulty, and Hugh of Saint Victor as a wise and sympathetic representative of a different view. Both repeatedly use labyrinthine language to discuss verbal complexity.

Arguing that poetic obscurity should not be condemned, Boccaccio responds to the charge that poets wish "to make an incomprehensible [inextricabile] statement appear to be wrought with exquisite artistry" $\left(\mathrm{O}_{5} 8 / \mathrm{R}_{5} \mathrm{O}\right)$ - all flash, no substance, as it were. If poets and rhetoricians are obscure, he asks, what of philosophers, whose entangled words admit no consistent interpretation? what of Holy Writ itself, crammed with obscurity and ambiguity, as befits the word of the "sublime Artificer of the Universe" $\left(\mathrm{O}_{59} / \mathrm{R}_{51}\right)$ ? Boccaccio categorizes textual difficulties: some problems lie in the eye of the dull beholder, others in a subject's inherent complexity, and still others in the practice of veiling truth with art to protect deep meaning from unworthy eyes (as a maze sometimes protects hidden knowledge). The artist's aim in this last case is not "to deprive the reader of the hidden sense, or to appear the more clever; but rather to make truths which would otherwise cheapen by exposure the object of strong intellectual effort and various interpretations, that in the ultimate discovery they shall be more precious" $\left(\mathrm{O}_{0} / \mathbf{R}_{52}\right)$. Poetic obscurity, then, is always "extricabilis" to the seeker: "I repeat my advice to those who would appreciate poetry and unwind its difficult involutions. You must read, you must persevere, you must sit up nights, you must inquire, and exert the utmost power of your mind. If one way does not lead to the desired meaning, take another; if obstacles arise, then still another; until, if your strength holds out, you will find that clear which at first looked dark" $\left(\mathrm{O}_{2} / \mathrm{R}_{54}\right)$. This reads very like counsel to someone in a multicursal maze, and indeed Boccaccio is showing how labyrinthine art begets a hermeneutic labyrinth. Whether the art in question is poetry, sacred scripture, or philosophy, the advantages of difficulty are the same, and Boccaccio quotes Augustine to express them: "Perhaps the words are rather obscurely expressed for this reason, that they may call forth many understandings, and that men may go away the richer, because they have found that closed which might be opened in many ways, than if they could open and discover it by one interpretation. . . [There is obscurity] not in order that it may be denied thee, but that it may exercise him that shall afterward receive it" $\left(\mathrm{O} 60-61 / \mathrm{R}_{52}\right)$. Petrarch supplies further justification for difficulty, which pleases and profits: "What we acquire with difficulty and keep with care is always the dearer to us" $\left(\mathrm{O}_{2} / \mathrm{R}_{53}\right)$. Such reasoning is of ten used to justify the writing of allegory, which is partly what Boccaccio is doing here; but it also applies to secular, purely recreative poetry, and indeed the troubadours' discussions of their complex art bear witness to the fact that many medieval people "delight in knowing and also in the effort of acquiring knowl- 
edge."62 "The fascination of what's difficult," to quote Yeats, is a constant pressure in medieval aesthetics; the lure of the labyrinth is endlessly attractive, and perhaps Aristotle had the explanation when he observed that "it is ... pleasant to complete what is defective, for the whole thing thereupon becomes our own work"63 — not that difficult poetry is defective in the sense of being flawed, but rather that, as reader response theories of literature recognize, it demands the active engagement of readers who help create the meaning of a text by filling in what Wolfgang Iser would call its gaps and indeterminacies and who thus value what they themselves have done. When we complete the course of the labyrinth, we value the center all the more. ${ }^{64}$

Yet complexity is dangerous, and not just for writers who become as entangled in their own creations as Daedalus was. Hugh of Saint Victor, concerned lest his own work be considered a fruitless labyrinth, was sensitive to the tension between necessary or productive difficulty and frustrating perplexity, and he offers a balanced response to apologiae like Boccaccio's. He acknowledges the difficulties of scripture, which not only follows artificial order frequently but also is itself both a well-built domus and a bewildering, trackless forest. Such complexity causes students of equal abilities but different mental habits to have different experiences in reading:

The one penetrates it [the text] quickly.... The other labors long and makes little progress.... Consider two men both travelling through a wood, one of them struggling around in bypaths but the other picking the short cuts of a direct route: they move along their ways with the same amount of motion, but they do not reach the goal at the same time.... Therefore, whoever does not keep to an order and a method in the reading of so great a collection of books wanders as it were into the very thick of the forest and loses the path of the direct route. ${ }^{65}$

There is a guide through the divine complexity that so resembles the labyrinths of the Queste or Jerome: the Seven Liberal Arts, the Trivium

62. For the troubadours, see Paterson, The Troubadours and Eloquence, passim; the quotation is from Geoffrey of Vinsauf (N89, F259).

63. Aristotle, Rhetoric 1.11, p. 72.

64. I cannot resist mentioning the work of Dennis Oppenheim, who constructed a vastly enlarged replica of a simple laboratory maze by deploying bales of hay on a field. He ran cattle through the maze, which they devoured as they progressed. Oppenheim notes, "In solving the maze they learned it. They digested the information that they were housed in" (“Janet Kardon Interviews Some Modern Maze Makers," Art International, 20 [April-May 1976], p. 67). Oppenheim has thus created a fascinating objective correlative for the process of learning by wandering through a maze as well as for the delicious satisfaction of solving labyrinthine difficulties.

65. I quote Taylor's translation, Didascalicon 5.5 (pp. 126-127). For scripture as domus, see Didascalicon 6.4; for artificial order, see 6.7. 
and Quadrivium, so named "because by them, as by certain ways [viae], a quick mind enters into the secret places of wisdom."66 If scripture's artificial order and semantic complexity frustrate untrained minds, secular poetry and philosophy are still worse, for they "are always taking some small matter and dragging it out through long verbal detours [ambagibus], obscuring a simple meaning in confused discourses." Anyone who "willingly deserts truth in order to entangle himself in these mere by-products of the [true] arts, will find, I shall not say infinite, but exceedingly great pains and meager fruit." 67 The involutions of the sacra pagina are worth the trouble of penetrating, but rhetorical and dialectical flourishes and circumlocutions in a lesser cause are problematic. Yet for Hugh even this circuitous and ambiguous literature may be profitable, for we learn better when entertaining literature occasionally offers light relief from serious study, and "we sometimes more eagerly take up a thought we come upon in the midst of a story." 68 By implication, secular labyrinthine literature can be relaxing, preparing readers for something better and sometimes even instructing them, but one wouldn't want to make a steady diet of it.

Other medieval writers, interested in the potential utility of their work, knew that excessive difficulty could imprison readers or listeners in a labyrinth of words like the one Macrobius bemoaned. Not everyone would approve of Boccaccio's lack of concern for those who cannot penetrate obscurities. Thus Boncompagno da Signa, lawyer-rhetorician, warns of leading people into epistemological labyrinths of definitions or mazes of prolixity, and Agobard of Lyons, as early as the ninth century, urged the meticulous correction of texts so that careless errors might not create "such confusion that nothing at all can be understood" or make "the order of divine words to be changed and the text of truth to be woven into a labyrinth of error." 69 Quite apart from the dangers of leading people into heresy, medieval authors, even secular ones, were intensely aware of the need to communicate effectively with mixed audiences: the troubadour Giraut de Bornelh thus rejects the obscure trobar clus for a style "that all people may understand," noting that "I could certainly make the song more veiled [cobert], but a song does not have a perfect reputation when not everyone can share in it"; yet at the same time he admits that he cannot realistically expect "to sing to every-

66. Hugh, Didascalicon $3 \cdot 3$ (p. 87 ).

67. Hugh, Didascalicon $3 \cdot 4$ (p. 88).

68. Hugh, Didascalicon 3.4 (p. 89).

69. See Boncompagno, Rhetorica novissima, pp. 257 and 280; for Agobard, Epistola 18, MGH Karol. aev. epist. 5, ed. E. Dümmler (Berlin, 1899), p. 233. Boncompagno's penchant for belaboring linguistic labyrinths is presumably related to his general interest in an intelligible rhetorical style: see Ronald G. Witt, "Boncompagno and the Defense of Rhetoric,"JMRS, 16 (1986), $1-31$. 
one communally."70 Preachers were exceptionally alert to the challenge of speaking artistically for the learned and clearly for the ignorant, as Guibert de Nogent (twelfth century) witnesses: "Though he [the preacher] preaches simple and uncomplicated matter to the unlettered, at the same time he should try to reach a higher plane with the educated; let him offer to them what they are capable of understanding." 71 Usually authors or preachers try to satisfy both audiences by blending clear doctrine, amusing examples, and subtle allegories. But as preaching techniques, given elaborate exposition in artes praedicandi that flourished in the later Middle Ages, became ever more sophisticated, exaggerated complexity and difficulty grew common. If the poetry of the troubadours, the dolce stil nuovo, and the Gawain-poet was brilliantly complicated, so too were Oxford and Paris university sermons whose labyrinthine aesthetic is reflected in Th.-M. Charland's comment that "the English preacher loves complication for the sheer pleasure of emerging from it skillfully."72 Thus the Dominican Thomas Waleys (d. ca. 1349) cautions preachers against paying more heed to elegant words than to clarity of thought lest the congregation grow confused and forgetful, and although he appreciates the exquisite dilation of a theme which provides many paths to meaning, he chastises sermonizers so fond of curiosity and eloquence that they create too many divisions of the theme and collect too many authorities in support of their points. ${ }^{73}$ In other words, he is distressed by overcomplication, by formal and stylistic labyrinths that bewilder the less sophisticated. Robert of Basevorn, writing in 1322 , highlights the perilous intricacies of sermon structure in his comments on Circuitous Development (circulatio), which presupposes a division of the sermon's theme into three parts, which are again divided into three, thus:

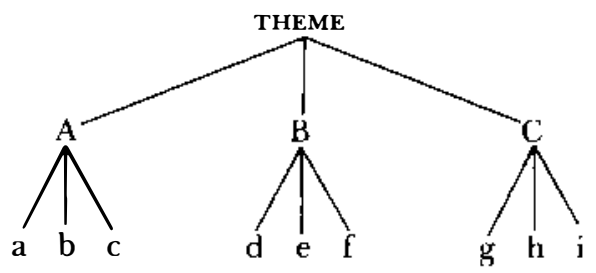

70. Paterson's translation, The Troubadours and Eloquence, pp. 91-92, 94.

71. From Guibert, A Book about the Way a Sermon Ought To Be Given, trans. Joseph M. Miller, in Readings in Medieval Rhetoric, ed. Joseph M. Miller, Michael H. Prosser, and Thomas Benson (Bloomington: Indiana University Press, 1973), p. 170.

72. Charland, p. 133. Charland has a useful introduction to medieval preaching and prints the text of Thomas Waleys's De modo componendi sermones and Basevorn's Forma praedicandi. See also Murphy, Rhetoric in the Middle Ages, chap. 6.

73. Charland, pp. 335 and 391 . Will might have progressed more quickly through the labyrinths of Piers Plowman had his mentors heeded Waleys's advice. 
Circuitous Development ... is . . an artificial linking of the first part of the last principal statement to the second part of the first principal statement, namely, $g$ to $b$, and again the linking of the second part of the last principal statement, namely $h$, to the third part of the first principal statement, namely $c$. This double connection of the last to the first is called Circuitous Development, so that if either connection is lacking there is no encirclement [circulatio]. It is called Circuitous Development in the image of extending a circle where the end and the beginning are the same. ${ }^{74}$

If this formula sounds labyrinthine, it is, and Robert knows it: "Some doubt the usefulness of this ornament. I know that it is more decorative than useful [magis curiosum quam utile]. I generally do not use it even if it presents itself, because it dulls the mind of the listener by making an unsolvable labyrinth [inexplicabile labyrinthum], unless the listener is very subtle." What is intelligible interlaced ornament to the learned leaves others in confusion, with typical labyrinthine relativity.

Labyrinthine writing was not universally privileged in the Middle Ages, nor did all literature conform to the labyrinthine aesthetic promulgated by many rhetorical handbooks. Some writing and preaching aim chiefly at being comprehensible; naturally, such works of ten use the plain or humble style to instruct directly, straightforwardly, of fering an unimpeded path to an important goal no one can afford to miss. Some literature is more elaborately constructed but not particularly confusing: the tale of Gardinus from the Gesta Romanorum, for instance, carefully glosses and retraces its circuitous and figurative steps to ensure understanding, taking readers by the hand after giving them a chance to make discoveries on their own. Such works are partially labyrinthine in their tactics. Other writings, like the Queste del Saint Graal or Piers Plowman or Pearl, are consistently labyrinthine: ornate and circuitous in form and expression, they necessitate frequent interpretive choice, and although their circlings and digressions may confuse us, that confusion is part of our education and enjoyment. And some works-Sir Gawain and the Green Knight, Chaucer's Canterbury Tales-are labyrinthine in the extreme, privileging ambiguity from start to finish even as they are laid out in superbly articulated and cross-related patterns; these works are paragons of labyrinthicity as artifacts and processes alike.

For many medieval writers, then, an artistically wrought text is very like a labyrinth: difficult, complex, circuitous, digressive, full of profitable and pleasurable ambages, having circumlocutions and ambiguities of the sort one finds routinely in allegory. Formally, such texts have the elaborate and appropriate structure so of ten linked with Daedalian artifacts. However, the meaning is explicable only with beneficial effort,

74. Robert of Basevorn, in Three Medieval Rhetorical Arts, pp. 190-191, and Charland, pp. 301-302. 
and the process of the text-how it says what it says-may rival the content in importance, just as, in a labyrinth, the process of getting to the center is (at least in theory) more than half the fun and most of the learning experience. The process and meaning of the text may even be the same: readers can learn what the text has to teach them only by laboriously tracing all the implications of the narrative's ambiguous and confusing path. Much labyrinthine narrative constitutes a Bildungsroman for protagonist and reader alike. ${ }^{75}$ Both text and labyrinth are obscure in all the right ways, thereby providing effective learning, the joy of discovery, and active participation in creating textual meaning. As allegory veils truth from casual and scornful observers, so the poetry of the labyrinth protects its full meaning as carefully as the imperial maze emblem protected the mysteries of the ruler. If labyrinths need explication, so do labyrinthine texts, whether the explication comes through the guidance of a commentary or preacher or through readers' flight on their own wings of contemplation. Naturally, the complex text contains labyrinthine dangers: careless readers or listeners may be lost, lazy, or seduced into interminable error; the goal may seem trivial in comparison to the labors involved in reaching it. But the ideal labyrinthine text is finally penetrable and extricable, albeit with difficulty, for its intended audience; it is as useful and magnificent a work of art as the ancient buildings, proving that persistent artistry and equally persistent interpretive labors triumphantly convert confusion and chaos into order and meaning. Such is the labyrinthine aesthetic that characterizes much great medieval poetry as well as great works of other ages-a Shakespearean play, a Bach fugue, a ballet by Sir Frederick Ashton, novels by Proust or Calvino, works in which both process and content are important, in which inextricable difficulty gives way to an epiphany of order created jointly by the structures of the work and the interpretive activity of audience or reader.

Such, then, is my hypothetical reconstruction of the links between the parallel systems of labyrinth and poetry considered as process and product. Because the labyrinth of ten had pejorative associations in medieval moral writings, the analogies between maze and poetry are usually inexplicit, and it may well be that few writers consciously saw the labyrinth as model for the creation and reception of literary texts. Nevertheless, I contend that the medieval idea of the labyrinth does in fact constitute such a model, illuminating and underlying a good deal of poetic theory and practice. Seen as a magnificent artifact, the domus daedali is a model for the carefully crafted literary domus. As a laborious process of artistic making, of the careful intertwining and ordering of circuitous paths, it is a model for poetic and rhetorical composition. As an initially confusing 
process to be experienced, understood, and transcended, it is a model for the hermeneutic process. After all, a good labyrinth of words is designed to be comprehended: it leads to valuable goals (new knowledge, relaxation, improvement of skills), and its ambiguous, difficult method of reaching those goals is both pleasurable and instructive. A bad verbal labyrinth, on the other hand, privileges empty or overly ornate artistry at the expense of eventual comprehension: the medium is the only message. Such texts are pejoratively called labyrinths.

My chief concern here has been literary theory, and I have necessarily indulged in a great deal of speculation. Demonstration of the actual practice of writing consciously-one might even say self-consciouslylabyrinthine texts must await substantial exposition in Part Three, which describes an extraordinary sequence of richly crafted labyrinths of words: Virgil's Aeneid, Boethius's Consolation of Philosophy, Dante's Divine Comedy, and Chaucer's House of Fame. 
